\title{
視覚あるいは触覚による自動車助手席の座り心地評価
}

\author{
信州大学繊維学部 西 松 豊 典(会員) \\ 信州大学䋐維学部 有賀 秀 樹 \\ 信州大学繊維学部鳥羽栄治
}

\section{Sitting Comfort of Automotive Assistant's Seat Evaluated by Visual or Tactual Sense}

\author{
Toyonori Nishimatsu, Hideki Ariga and Eiji Toba \\ Faculty of Textile Science and Technology, Shinshu University, Ueda
}

\begin{abstract}
A sitting comfort of automotive assistant's seat was evaluated by a visual sense or a tactual sense of consumer. The comfort terms used for the evaluation by the visual sense were compared with those by the tactual sense and the relation between tactual sensory values and physical properties of automotive seats was examined by the use of factor analysis. The results are as follows.

(1)As the result of factor analysis, two factors, namely, "elegant" and "sporty" were selected on evaluating the sitting comfort of automotive assistant's seats by each sense.

(2)The contacting area between the seat and human buttocks in the high grade car was bigger and the pressure was smaller than those in the low grade car.

(3)The four tactual sensory values "soft", "warm", "curved" and "voluminous" related with the sitting comfort were affected by the ischial tubercle weight, the pressure and the contacting area between the seat and human buttocks.
\end{abstract}

(Received March 27, 1995)

摘

(Accepted for Publication September 5, 1995)

目的 自動車助手席に対する座り心地イメージを, 視覚あるいは触覚だけで評価した視覚イメージ形容語と触覚イメージ形 容語との対応関係を因子分析を用いて検討した. さらに, 体圧分布センサーシートおよび圧力センサーを用いて着座時の被験者 の圧力分布を計測し, 触覚だけで評価した座り心地官能量と触覚物理量（特に体圧分布量, 座骨結節荷重）との相関関係につい て考察した。

成果 因子分析結果より, 被験者が視覚あるいは触覚のみで評価する自動車助手席の座り心地は, 2 因子（上品さやスポーテ イ感に関連する形容語）で表現される，また，体圧分布より，高級車に着座した場合，中級車および大衆車と比較して被験者の 歪部とシート座部との接触面皘が大きくなるが, 平均圧力は小さくなる傾向がみられた. さらに, 触覚により評価した座り心地 官能量と各触覚物理量との関係を検討した結果, 各物理量との相関が高い形容語は「柔らかい」「「あたたかい」、「曲線的な」,「ボ リューム感がある」であった.

(平成 7 年 3 月 27 日受理) (平成 7 年 9 月 5 日審查終了)

\section{1. 緒 言}

自動車のハードウェア性能が高度化するにつれ て, 長時間直接接触するシートに対する消費者の要
求性能は一層高まっているが, シートの座り心地設 計は従来から設計者の経験に依存している。なぜな らば, シートに関連する種々の物理量が複雑にヒト の視覚や触覚へ影響を及ぼしているからである. 
そのため, 座り心地の定量化は従来より種々試み られ (4) $^{1 \sim}$ シートの座り心地官能評価量とシート自体 の物理量（曲げかたさ，圧縮特性等）との対応関係 が考察されている. しかし, これらの研究では座り 心地を評価する形容語が専門的すぎること，官能評 価実験の対象者が消費者ではなく自動車の開発に従 事している専門家であること, シートの評価は視覚 によってあ影響されると考えられるが専門家の触覚 だけでシートの座り心地が評価されていること, シ 一トの設定が運転席, 助手席であるのか明確でない 等の問題点がある.

そこで, 本研究では被験者を消費者に限定すると ともに自動車シートを助手席と設定し, 助手席の座 り心地に対するイメージを視覚, あるいは触覚のみ によって評価した視覚イメージ形容語と触覚イメー ジ形容語との対応関係を検討した。 さらに，体圧分 布センサーシートおよび圧力センサーを用いて着座 時の被験者の圧力分布を計測し, 触覚だけで評価し た座り心地官能量と触覚物理量（特に体圧分布量, 座骨結節荷重）との相関関係を考察した.

\section{2. 視覚によるシートのイメージ評価}

シートの座り心地に関係があると思われる形容語 を自動車雑誌等より 52 種類選択し，その中から被験 者が分かりにくいと判断した形容語を除外し，「柔 らかい」,「スポーティな」,「曲線的な」,「ゆったり した」,「高級感がある」「重い」「「あたたかい」,「す っきりした」,「明るい」,「すべすべした」,「平ら な」「「上品な」,「ボリューム感がある」の 13 種類を 視覚形容語として用いた.

図 1 に示すようなシート写真 (助手席) を 5 種類 (高級車 2 種類, 中級車 2 種類, 大衆車 1 種類) 用意 し, その中から 2 種類ずつ組み合わせた 10 対の写真 を被験者50名に提示して, 各形容語について一対比 較法による視覚官能検查を判定時間を制約せずに行 った．写真を用いたのはシートの色を同一明度にす るためである. また, 各シートの構造は 3 層構造 (人体に接する表皮層, パッド層, 振動衝撃を和らげ るスプリング層）であり，表皮層の材質はポリエス テル $100 \%$ ，パッド層の材質はポリウレタン $100 \%$ である、座部および背もたれ部の最大幅および最大 長さを表 1 に示す.

官能検查方法は, 例えば形容語「柔らかい」につ いては次のようである.

一対の自動車助手席写真（A, B) を見て,

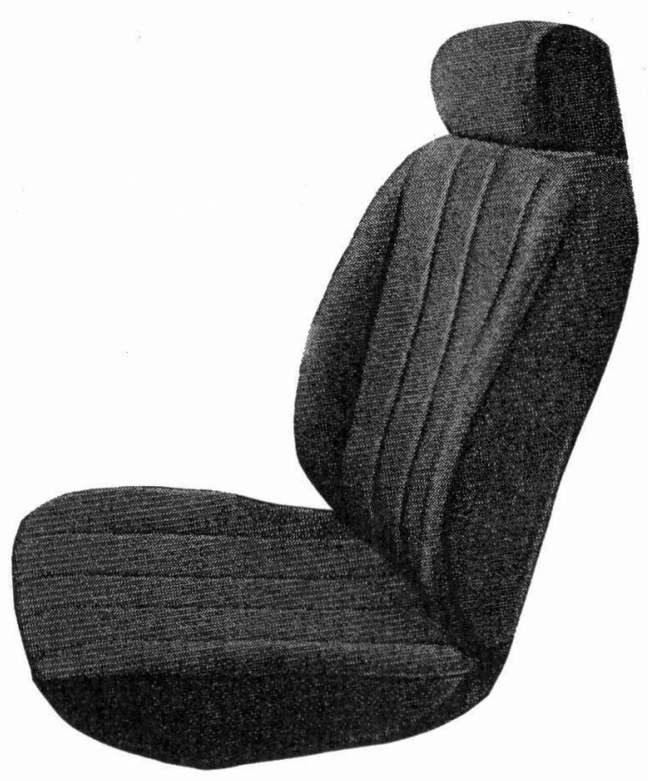

Fig. 1 A photograph of car seat used in visual sensory test

Table 1 Details of each seat

\begin{tabular}{|c|c|c|c|c|c|}
\hline & & \multicolumn{2}{|c|}{ Seat cushion } & \multicolumn{2}{|c|}{ back-rest of seat } \\
\hline \multicolumn{2}{|l|}{$\cdot$} & $\begin{array}{l}\text { Maximum seat } \\
\text { width (mm) }\end{array}$ & $\begin{array}{l}\text { Maximum seat } \\
\text { length }(\mathrm{mm})\end{array}$ & $\begin{array}{l}\text { Maximum seat } \\
\text { width (mm) }\end{array}$ & $\begin{array}{l}\text { Maximum seat } \\
\text { length }(\mathrm{mm})\end{array}$ \\
\hline \multirow{2}{*}{$\begin{array}{l}\text { High } \\
\text { class } \\
\text { seat }\end{array}$} & A & 562 & 515 & 532 & 588 \\
\hline & B & 535 & 508 & 522 & 587 \\
\hline \multirow{2}{*}{$\begin{array}{l}\text { Middle } \\
\text { class } \\
\text { seat }\end{array}$} & $\mathrm{C}$ & 520 & 505 & 520 & 535 \\
\hline & $\mathrm{D}$ & 525 & 500 & 506 & 540 \\
\hline $\begin{array}{l}\text { Low } \\
\text { class } \\
\text { seat }\end{array}$ & $\mathrm{E}$ & 515 & 483 & 520 & 556 \\
\hline
\end{tabular}

-A は B より非常に柔らかい +2 点

- A は B よりやや柔らかい +1 点

- A と B は差がない 0 点

- B は A よりやや柔らかい - 1 点

- B は A より非常に柔らかい -2 点

の 5 段階で判定を行わせた.

一対比較法で50名の被験者が官能評価を行った結 果より, シェッフェの変形一芳賀の変法 ${ }^{5}$ を用いて 各形容語に対する 5 種類の助手席の平均嗜好度を求 
めた.

そして, 各視覚形容語間の関係を明らかにするた めに, 各形容語の平均嗜好度について因子分析法を 適用して検討した。すなわち，50名の被験者が10対 の助手席の組み合わせについて 1 回ずつ評価した 13 種類の形容語に対する 5 種類の助手席の平均嗜好度 間の相関係数行列を基に主因子解法により因子負荷 量を求めた。 さらに, バリマックス法で因子軸を回 転して得た因子負荷量を表 2 に示す。なお，共通因 子の抽出を第 2 因子までで打ち切ったのは, 因子寄 与率が 100\%となったからである.

表 2 より，第 1 因子には，「柔らかい」「「あたたか い,「明るい」,「平滑感」,「上品な」,「ボリューム 感がある」, 第 2 因子には,「スポーティな」,「助手 席の形状」「軽重感」の意味が含まれていることが 分かる. 2 因子に対する因子負荷量の大きさより, 第 1 因子には助手席の上品なイメージに関連する形 容語，第 2 因子には助手席のスポーティなイメージ に関連する形容語がみられる.

また，相関係数行列より形容語「上品な」と相関 が高い形容語は「柔らかい」「「あたたかい」,「明る い」「「゙リューム感がある」と正の相関,「すべすべ した」と負の相関であった。「スポーティな」は「曲

Table 2 Factor loading matrix on visual sensory test

\begin{tabular}{l|r|r}
\hline \multirow{2}{*}{ Adjective } & \multicolumn{3}{|c}{ Common factor } \\
\cline { 2 - 3 } & \multicolumn{1}{|c|}{1} & \multicolumn{1}{|c}{2} \\
\hline 1 Soft & 0.811 & -0.585 \\
2 Sporty & -0.276 & 0.961 \\
3 Curved & 0.515 & -0.860 \\
4 Comfortable & 0.711 & -0.704 \\
5 High-class & 0.703 & -0.712 \\
6 Heavy & 0.519 & -0.856 \\
7 Warm & 0.815 & -0.579 \\
8 Shapely & -0.711 & 0.704 \\
9 Cheerful & 0.866 & -0.500 \\
10 Smooth & -0.806 & 0.592 \\
11 Flat & -0.675 & 0.737 \\
12 Elegant & 0.970 & -0.242 \\
13 Volumious & 0.786 & -0.619 \\
\hline Proportion of & 52.7 & 47.3 \\
total variance & & \\
\hline & &
\end{tabular}

線的な」「重い」と負の相関が高い.すなわち,「柔 らかく，あたたかく，明るく，ボリューム感があり， ざらざらした感じ」の助手席を視覚的に認識する場 合, 消費者は「上品な」と評価すること,「直線的で, 軽い」と視覚認識する助手席を「スポーティな」と 評価していると考えられる。

\section{3．触覚によるシートの座り心地評価}

視覚評価で用いた 5 種類（高級車, 中級車, 大衆 車）の助手席より，2 種類ずつ組み合わせた 10 対の 助手席をランダムに選択し，おのおのへ被験者20名 を着座させた，視覚官能検査と同様の一対比較法で 各触覚形容語について触覚のみによる座り心地評価 を 1 回ずつ行わせた。 なお，触覚官能検查を行う場 合, 被験者は目隠しをして視覚による影響を全く除 いた状態で行い，判定時間は制約しなかった。

座り心地評価に用いた触覚形容語は, 視覚評価で 抽出した 9 種類の形容語より触覚では評価が難しい 「明るい」,「重い」を除いた 7 種類の形容語「柔らか い」,「あたたかい」,「すべすべした」,「上品な」「「ボ リューム感がある」,「スポーティな」,「曲線的な」 と,「ホールド感」を加えた 8 種類である.

なお，触覚官能検査に用いた自動車座席は床面か ら座面前部中央までの垂直高さを $26 \mathrm{~cm}$, 座部と背 むたれ部間の角度を $110^{\circ}$ と設定し，シートの表面 素材はモケット（ポリエステル 100\%), 形状は市販 乗用車セダンタイプに使用されているシート，色は グレーと統一した。ここで，座部と背あたれ部間の 角度を $110^{\circ}$ 之設定したのは, 事務用椅子に座った ときに快適と感じる角度が $110^{\circ}$ だからである ${ }^{6}$.

そして, 一対比較法で10対の助手席の組み合わせ について 8 種類の触覚形容語を評価した結果より, 各形容語における 5 種類の助手席の平均嗜好度を求 めた.これらの平均嗜好度間の相関係数行列を基に 主因子解法により因子負荷量を求めたのち，バリマ ックス法で因子軸を回転して得た因子負荷量を表 3 に示す. 共通因子の抽出を第 2 因子までで打ち切っ たのは，因子寄与率が 100\%となったからである.

表 3 より, 第 1 因子には, 「柔らかい」,「あたたか い」「曲線的な」,「すべすべした」,「上品な」,「ボ リューム感がある」, 第 2 因子には,「スポーティ な」「ホールド感」の意味が含まれていた。すなお ち，2因子に対する因子負荷量の大きさより第 1 因 子には助手席の上品なイメージに関連する形容語, 第 2 因子には助手席のホールド性に関連する形容語 
Table 3 Factor loading matrix on tactual sensory test

\begin{tabular}{l|r|r}
\hline \multirow{2}{*}{ Adjective } & \multicolumn{2}{|c}{ Common factor } \\
\cline { 2 - 3 } & \multicolumn{1}{|c|}{1} & \multicolumn{1}{|c}{2} \\
\hline 1 Soft & 0.909 & 0.416 \\
2 Sporty & 0.532 & 0.856 \\
3 Warm & 0.898 & 0.436 \\
4 Hold & -0.047 & 0.992 \\
5 Curved & 0.875 & 0.484 \\
6 Smooth & 0.988 & 0.039 \\
7 Elegant & 0.997 & -0.053 \\
8 Voluminous & 0.983 & 0.177 \\
\hline Proportion of & 70.0 & 29.0 \\
total variance & & \\
$\quad$ (\%) & & \\
\hline
\end{tabular}

\section{がみられる。}

ここで，形容語「上品な」は「柔らかい」「あた たかい」、「曲線的な」,「すべすべした」,「ボリュー ム感がある」と，「スポーティな」は「ホールド感」 と正の相関が高い。この結果は，スポーッタイプの シートがホールド性を重視していることと一致して いる.

次に, 両感覚に共通な 7 種類の形容語「柔らか い」「「あたたかい」,「すべすべした」,「上品な」,「ボ リューム感がある」,「スポーティな」「曲線的な」 について, 視覚による官能評価値（平均嗜好度）と 触覚による官能評価値間の相関係数を検討すると,

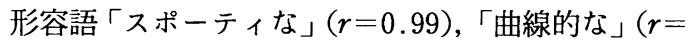
0.88）が高く,これらの形容語については視覚と触 覚の評価が一致した。 しかし, 他の形容語について はあまり相関がみられず，これらの形容語を視覚で 評価する場合と触覚だけで評価する場合では, 評価 基準が異なっていると考えられる.

\section{4. 触覚による座り心地評価值と触覚 物理量との関係}

触覚による官能検查を行った条件と同様にして 5 種類の助手席へ被験者を着座させ, 着座中の被験者 の腎部における座骨結節荷重および体圧分布を以下 の 2 種類の方法で測定した. なお, 被験者は各測定 法について20名であり, 触覚官能検査を行った同一 人である.
直径 $10.5 \mathrm{~mm}$ の圧力センサー（共和電業(侏製）2 個を被験者の贀部の座骨結節部 2 か所に貼付し, 着 座時の座骨結節荷重を測定した。

また, シート形状の体圧分布センサーシート （BIG-MAT，ニッ夕(侏製）を助手席座部に設置し， 被験者が着座したときの㙠部および大腿部の体圧分 布を測定した。 そして，着座して $2 \mathrm{~min}$ 経過後，体 圧分布より助手席と被験者の腎部および大腿部間の 平均圧力および総接触面積を求めた。 なお，両湘定 法とも被験者には助手席座部の最後部に慰部が当た るように着座させた。

測定に用いたセンサーシートは，加わる荷重の大 きさに応じて電気抵抗值が変化する薄膜上下に行電 極と列電極を一定間隔でマトリックス状に配置し， 各交点で荷重を検出する構造となっており, 測定範 囲は $43 \times 48 \mathrm{~cm}$, 測定箇所は 2064 点である。ここで, 平均圧力とは測定箇所 2064 点における各圧力を平均 したものである.

センサーシートで 3 車種（高級車，中級車，大衆 車）の助手席に着座しているときの被験者の体圧分 布を測定した一例を図 2 に示す。

図 2 より, 各車種とも被験者は腎部の 2 箇所の座 骨結節点を中心として体格に応じた圧力分散を示し ていることが分かる。このような体圧分布の傾向 は，他の被験者についても同様の傾向を示した。

圧力センサーおよびセンサーシートを用いて, 助 手席に着座中の各被験者の座骨結節荷重, 座部との 平均圧力および接触面積について 5 回測定し, 全被 験者の平均值を求めた。なお，同一車種に関する測 定値について分散分析を行った結果, 個人内および 個人間について有意差なしであった。

座骨結節荷重は高級車 $\left(140.8 \mathrm{~g} / \mathrm{cm}^{2}\right) \fallingdotseq$ 中級車 $\left(139.2 \mathrm{~g} / \mathrm{cm}^{2}\right) \rightarrow$ 大衆車 $\left(100.1 \mathrm{~g} / \mathrm{cm}^{2}\right)$ の順に, 平 均圧力は大衆車 $\left(57.2 \mathrm{~g} / \mathrm{cm}^{2}\right) \rightarrow$ 中級車 $(55.7 \mathrm{~g} /$ $\left.\mathrm{cm}^{2}\right) \rightarrow$ 高級車 $\left(52.3 \mathrm{~g} / \mathrm{cm}^{2}\right)$ の順に, 座部之の平均 接触面積は, 高級車 $\left(912.7 \mathrm{~cm}^{2}\right) \rightarrow$ 中級車 $(852.8$ $\left.\mathrm{cm}^{2}\right) \rightarrow$ 大衆車 $\left(732.8 \mathrm{~cm}^{2}\right)$ の順に減少する傾向が みられた。

このように，高級車に着座した場合にはヒトの慰 部と助手席座部との接触面積が大きくなるが，平均 圧力は小さくなることが分かった。

これは, 高級車の助手席はスプリングが柔らかく 座部面積が大きいので，スプリングが硬く座部面積 が小さい大衆車の助手席と比較して, 被験者と座部 間の接触圧力が小さくなるとともに接触面積が大き 
(a)

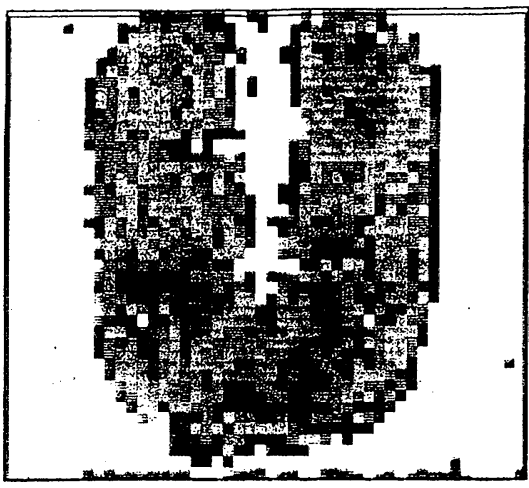

$8 \mathrm{~g} / \mathrm{cm} 2$

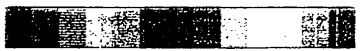

(b)

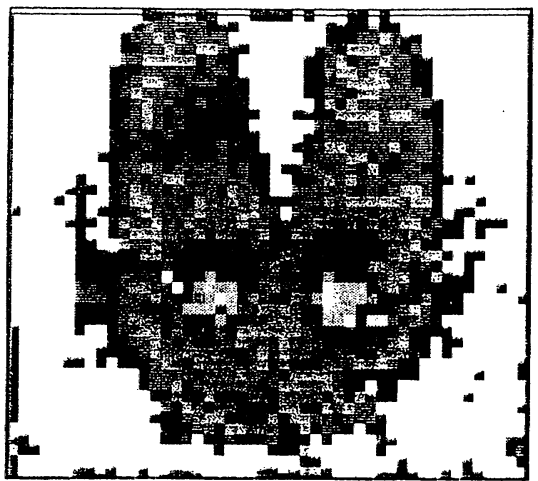

$8 \mathrm{~g} / \mathrm{cm} 2$

$180 \mathrm{~g} / \mathrm{cm} 2$

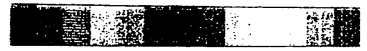

(c)

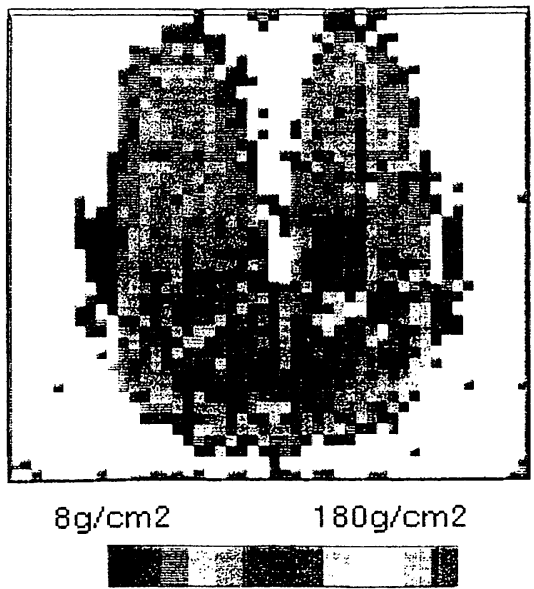

Fig. 2 Pressure distribution between the car seat and human buttocks

(a)High-class car, (b)middle-class car, (c)low -class car.
くなると考えられる．

また，触覚による座り心地評価形容語と各触覚物 理量（座骨結節荷重, 座部との平均圧力および総接 触面積) との相関係数を表 4 に示す.

表 4 より, 座骨結節荷重と相関が高い形容語は 「柔らかい」「「スポーティな」「あたたかい」,「曲線 的な」「「ホリューム感がある」, 接触面積と相関が高 い形容語は「柔らか心」,「スポーティな」、「あたた かい」,「曲線的な」,「すべすべした」,「上品な」,「ボ リューム感がある」,「圧力と相関が高い形容語は 「柔らかい」「「たたかい」、「曲線的な」「「すべすべ した」,「上品な」,「ボリューム感がある」である. よって,「ホールド感」を除く 7 種類の形容語を被験 者が評価する場合には被験者の慰部とシート座部間 の接触面積の大小が影響すると考えられる。しか し,「ホールド感」については相関が高い物理量がな く, 今後さらに検討しなければならない。

\section{5. 結 言}

自動車助手席の座り心地を視覚あるいは触覚で評 価した視覚イメージ形容語と触覚イメージ形容語と の関係を検討するとともに，助手席着座時の被験者 の圧力分布を測定し，触覚だけで評価した座り心地 官能量と触覚物理量との相関関係を考察した。 その 結果は次のとおりである。

（1）因子分析結果より，被験者が視覚あるいは触

Table 4 Relation between tactual sensory values of sitting comfort and physical properties

\begin{tabular}{l|c|c|c}
\hline \hline Adjective & $\begin{array}{c}\text { Ischial tubercle } \\
\text { weight }\left(\mathrm{g} / \mathrm{cm}^{2}\right)\end{array}$ & $\begin{array}{c}\text { Contacting } \\
\text { area }\left(\mathrm{cm}^{2}\right)\end{array}$ & $\begin{array}{c}\text { Pressure } \\
\left(\mathrm{g} / \mathrm{cm}^{2}\right)\end{array}$ \\
\hline Soft & 0.96 & 0.99 & -0.91 \\
\hline Sporty & 0.96 & 0.83 & -0.54 \\
\hline Warm & 0.97 & 0.99 & -0.90 \\
\hline Hold & 0.62 & 0.36 & 0.05 \\
\hline Curved & 0.98 & 0.99 & -0.88 \\
\hline Smooth & 0.78 & 0.93 & -0.99 \\
\hline Elegant & 0.72 & 0.89 & -0.99 \\
\hline Voluminous & 0.86 & 0.97 & -0.99 \\
\hline
\end{tabular}


覚のみで評価する助手席の座り心地は 2 因子（上品 さやスポーティ感に関連する形容語）で表現され る.

（2）高級車の助手席に着座した場合，そのスプリ ングの柔らかさや座部面積の大きさより被験者の臂 部之座部との接触面積は低級車より大きくなるが, 平均圧力は小さくなることが分かった.

(3) 触覚による座り心地評価形容語と各物理量 （座骨結節荷重, 座部との平均圧力および接触面積） との関係を検討した結果, 各物理量との相関が高い 形容語は「柔らかい」,「あたたかい」「「曲線的な」, 「ボリューム感がある」であった。

本研究の一部は, 平成 6 年 6 月, 第47回日本繊維
機械学会年次大会（大阪市）で発表を行った.

\section{参考文献}

1）横倉千代勝; “シート表皮の感触と物理特性の対応につい $\tau^{\prime \prime}$ ，自動車技術，29，8，pp. 60-65（1975）

2）上條 健；“シート乗心地の定量的評価法”, 自動車技術, 36, 12, pp. 1305-1310 (1982)

3）八田一利, 上野由雪, 永島淑行; “自動車座席のクッション 性に関する研究”，人間工学，23，3，pp. 173-180 (1987)

4）岩崎信也, 松岡由幸, 山/井利美; “シート座り心地の定量 化”，自動車技術，42，11，pp. 1403-1408（1988）

5）日科技連官能検查委員会編；“官能検査ハンドブック”，pp. 374 (1973)

6）花岡利昌,栗正康子; “体圧と接触面積の変化よりみた休息 椅子の座り心地の良さの条件についで，人間工学，2，4, pp. 30-34 (1966) 